\title{
SISTEM POLITIK DAULAH/KERAJAAN: \\ KONSEPSI, BENTUK PEMERINTAHAN DAN \\ INSTITUSI POLITIK ALIRAN SYI'AH
}

\author{
Jainuddin. M. Hum. \\ Institut Agama Islam (IAI) Muhammadiyah Bima \\ Jln. Anggrek No. 16 Ranggo Na'e Kota Bima \\ jainuddin.ptais015@gmail.com
}

\section{Abstrak}

Perang Shiffin berakhir dengan arbitrase yang berakibat terbentuknya tiga fraksi politik waktu itu, pertama golongan khawarij, kedua golongan muawiyah, dan ketiga golongan Ali yang kemudian terkenal dengan sebutan Syi'ah. Kaum Syi'ah adalah pengikut setia Ali bin Abi Thalib. Keyakinan mereka yang amat tinggi kepadanya membawa kepada satu keyakinan bahwa Ali Bin Abi Thalib adalah alKhalifah al-Mukhtar (khalifah terpilih) dari Nabi Muhammad Saw., karena dianggap sahabat terbaik di antara sahabatsahabat lain. Artinya mereka meyakini bahwa yang berhak mengendalikan pemerintahan pasca Nabi meninggal adalah Iman; baik kepemimpinan politik maupun kepemimpinan spiritual (agama). Dan jabatan Imam adalah istimewa ahlul al-bait (keluarga Nabi), yaitu Ali Bin Abi Thalib dan keturunanya. Dalam hubungan ini al-Muzaffar mengatakan "kami meyakini bahwa Imamah adalah salah satu ajaran Islam yang fundamental (ushul al-din), dan keyakinan seseorang tak pernah menjadi sempurna tanpa meyakini imamah itu". Tulisan ini mengupas sisi lain dari perkembangan aliran politik syi'ah dalam peradaban Islam. Tulisan ini menggunakan pendekatan sejarah dan sosiologi Politik. pergolakan politik mazhab Syi'ah dalam pentas sejarah Islam melahirkan 
paham dan sekte-sekte yang beragam dan saling berseberangan. Para pemimpin dalam sekte Syi'ah saling mengklaim dan berebut pengaruh untuk mendapatkan pengikut dari dulu hingga sekarang. harus diakui dalam peta sejarah Islam Mazhab Syi' ah telah mampu membangun sebuah peradaban dan memberikan kontribusi dalam peradaban Islam ketika mazhab Syi'ah Ismailiyah membangun dinasti Fatimiyyah di mesir. Konsep Imamah dalam Mazhab Syi'ah merupakan konsep yang mempercayai Ali bin Abi Thalib yang berhak menggantikan posisi Nabi Muhammad sebagai pemimpin agama dan pemimpin Negara dari pada sahabat seperti Abu Bakar, Umar bin Khattab dan Utsman. Sebagian sekte-sekte tersebut tidak mengakui akan kepemimpinan Abu Bakar. Umar, dan Utsman dan menganggap mereka telah merampas hak Ali bin Abi Thalib sebagai penerima wasiat dari Nabi. Namun di sisi lain sekte-sekte syi'ah ada juga yang mengakui dan menerima kepemimpinan Abu Bakr, Umar, dan Utsman, sebagaimana halnya Syi'ah Zaidiyah namun tidak semua pecahan dari sekte Zaidiyah ini memiliki satu pendapat tentang hal demikian.

\section{Keyword; Konsep Pemerintahan, Aliran Politik, Syi'ah}

\section{A. Pendahuluan}

Suatu hal yang perlu mendapat catatan dalam dunia perpolitikan Islam. Nabi Muhammad Saw. dalam praktiknya baik mendirikan dan sekaligus memimpin Negara Madinah merupakan sebuah isyarat bahwasannya keberadaan sebuah Negara sangatlah penting. Namun Piagam Madinah yang menjadi sebuah kostitusi di era kepemimpinan Nabi Muhammad Saw. tidak menyebutkan agama Negara.

Sangaji Jurnal Pemikiran Syariah dan Hukum 
Terdapat teori-teori yang menimbulkan kegoncangan dalam sejarah Islam. Tetapi tidak bisa dikatakan bahwa itu adalah dari Islam. Dalam pendapat Abdullah bin saba' bahwa Ali bin Abi Thalib lah yang menerima wasiat dari Rasulullah sebagai pengganti beliau. Ia mengatakan bahwa setiap Nabi memiliki wasiat dan inilah yang menjadi pangkal keyakinan terhadap mazhab Syi'ah. Ia pun berkata: "Maka siapakah yang lebih lalim dari pada mereka yang tidak melaksanakan wasiat Rasulullah, Saw." selanjutnya berkata : "Sesungguhnya Utsman telah merampas hak khalifah kepada Ali. maka bangitlah kalian untuk menuntut soal ini dan mulailah mengecam para Gubernur yang ada. Dan tonjolkan perintah Allah untuk melakukan kebajikan dan mencegah kemungkaran". Ia juga merupakan orang yang pertama sekali menyinggung Abu Bakar dan Umar. ${ }^{1}$

Dalam catatan sejarah bahwa dengan diangkatnya Yazid oleh Muawiyah sebagai penggantinya maka hilang harapan "Keturunan Ali" untuk merampas kekuasaan dan kerajaan dari golongan Muawiyah. Yang sangat menyedihkan dalam peristiwa sejarah itu ialah cara terbunuhnya Husain. Hal mana meninggalkan kesan yang sangat menyedihkan baik di kalangan umat muslim pada umumnya apalagi dikalangan kaum Syi'ah. Peristiwa ini telah menjadikan kaum Syi'ah bertambah kuat dan kompak hingga dapat bertahan samapai sekarang.

Sebagaimana telah di ketemukan bahwa perang Shiffin berakhir dengan arbitrase, dan berakibat lahirnya tiga fraksi politik waktu itu, yaitu golongan Khawarij, golongan Muawiyah, yang berhasil membentuk Dinasti Umayyah dan menjadi imperium Islam pertaman dalam sejarah, dan golongan Ali yang kemudian terkenal dengan sebutan Syi'ah.

${ }^{1}$ Fuad Moh. Fachruddin, Pemikiran Politik Islam, (Jakarta: Pedoman Ilmu Jaya, 1988), hlm. 81 
Kaum Syi'ah adalah pengikut setia Ali bin Abi Thalib. Keyakinan mereka yang amat tinggi kepadanya membawa kepada satu keyakinan bahwa Ali Bin Abi Thalib adalah alKhalifah al-Mukhtar (khalifah terpilih) dari Nabi saw, karena ia dianggap sahabat terbaik diantara sahabat-sahabat Nabi. Artinya mereka meyakini bahwa yang berhak mengendalikan pemerintahan pasca Nabi adalah Iman baik kepemimpinan politik maupun kepemimpinan spiritual (agama). Dan jabatan imam adalah istimewa ahlul al-bait (keluarga Nabi), yaitu Ali Bin Abi Thalib dan keturunanya. Dalam hubungan ini alMuzaffar mengatakan "Kami meyakini bahwa Imamah adalah salah satu ajaran Islam yang fundamental (ushul al-din), dan keyakinan seseorang tak pernah menjadi sempurna tanpa meyakini imamah itu". ${ }^{2}$

\section{B. Perkembangan dan Hakikatnya.}

Kata Asy-Syi'ah secara etimologi berarti "sahabat" atau "pengikut". Sedangkan dalam terminologi para pakar ilmu kalam baik klasik maupun kontemporer diartikan sebagai pengikut Imam Ali bin Abi Thalib. ${ }^{3}$ Seluruh aliran Syi'ah bersepakat bahwa Imamah bukanlah kepentingan umum, yang persoalannya diserahkan kepada pada pendapat masyarakat dan pengangkatannya tergantung pada pengangkatan mereka.

Syi'ah juga merupakan kelompok masyarakat yang menjadi pendukung Ali bin Abi Thalib. Mereka berpendapat bahwa Ali bin Abi Thalib adalah imam dan khalifah yang ditetapkan melalui nash dan wasiat Rasulullah saw baik secara terang-terangan maupun secara implisit. Mereka beranggapan bahwa imamah tidak boleh keluar dari jalur keturunan Ali bin

${ }^{2}$ Muhammad Rida al Muzaffar, The Faith of Syiah Islam, (Ansariyah, Qum, 1989), hlm. 31

${ }^{3}$ Ibnu Khaldun, Muqaddimah, terj. (Jakarta: Pustaka Al-Katsar, 2011), hlm. 347

Sangaji Jurnal Pemikiran Syariah dan Hukum 
Abi Thalib. Jika pernah terjadi imam bukan dari keturunan Ali, hal itu hanya merupakan kedzaliman dari orang lain dan Taqiyah dari pihak keturunan Ali. Menurut mereka imamah bukan hanya dipandang sebagai kemaslahatan dengan di pilih atau di tunjuk, tetapi imamah termasuk akidah yang menjadi tiang agama. Mereka sepakat bahwa imamah wajib di tunjuk dan orangnya sudah dinashkan. Imamah wajib memiliki sifat terpelihara dari kesalahan ('ishmah) sebagaimana sifat yang terdapat pada diri Nabi. Imamah juga harus terbebas dari dosa besar dan dosa kecil. Mereka berpendapat bahwa ketentuan tersebut tidak boleh di tolak, baik melalui perkataan, perbuatan maupun keyakinan, kecuali dalam keadaan taqiyyah. Tetapi kelompok Syi'ah Zaidiyah mempunyai pendapat lain; mereka berpendapat bahwa imam boleh saja dari luar keturunan Ali. ${ }^{4}$

Pada saat khalifah ketiga Utsman bin Affan terbunuh. Seiring dengan perkembangan zaman, istilah Syi'ah lebih dinisbatkan pada kelompok pengikut Ali dan anak cucunya sehingga lambat laun tumbuh keyakinan bahwa khalifah dan kepemimpinan umat mutlak bagi keturunan Ahlul Bait. Kaum muslimin masih berbeda pendapat dengan nilai golongan ini, diantara mereka ada yang berpendapat bahwa Syi'ah merupakan kelompok pemahaman akidah saja, sedangkan sebagian yang lain berpendapat bahwa Syi'ah tidak lebih dari perwujudan rasa simpati terhadap Ali bin Abi Thalib.

Mereka yang berpendapat bahwa Syi'ah adalah aliran dalam pemahaman berdasarkan pernyataan Rasulullah saw sesudah melakukan haji Wada dihadapan kaum muslimin di Ghadir Khun. "Siapa saja yang menjadikan aku sebagai pemimpinnya maka ali adalah pemimpinnya. Ya Allah, bantulah

${ }^{4}$ Asy-Syahrastani, Al-Milal Wa Al-Nihal, Terj. Jilid 1 (Surabaya: PT. Bina Ilmu, 2006), hlm. 124 lihat juga Ibnu Khaldun, Muqaddimah, terj. Masturi Irham, Malik Supar, Abidun Zuhri (Jakarta: Pustaka Al-kautsar, 2011) hlm. 349-351 
orang-orang yang menjadikannya sebagai pemimpinnya, dan musuhilah orang-orang yang memusuhinya" (al-hadits)

Orang-orang Syi'ah berpendapat bahwa hadits tersebut merupakan wasiat Rasulullah Saw. Yang menghendaki Ali sebagai pemimpin dan Amirul Mukminin sepeninggalnya. Disamping hadits itu, masih ada sederetan nash lain yang mereka jadikan sebagai sandaran dalam meyakini bahwa khalifah adalah hak mutlak bagi Ali. Diantaranya: "Aku bagaikan kota Ilmu dan Ali adalah Pintunya", "kedudukan Ali bagiku bagaikan kedudukan harun bagi musa, hanya tidak lagi ada seorang Nabi yang diutusnya sesudahku" (al-hadits), "tidak ada seorangpun yang mencintaimu (Ali) kecuali ia seorang mukmin dan tidak akan ada seorang yang membencimu kecuali ia munafik" (al-Hadits).

Para pendukung Ali bin Abi Thalib beranggapan bahwa Ali adalah orang yang paling berhak atas jabatan khalifah dan bahwasanya Abu Bakar, Umar, dan Utsman dianggap sebagai orang-orang yang telah mengambil kepemimpinan yang di kuduskan daripadanya. Kekacauan yang melanda kaum muslimin karena langkah politik yang digariskan oleh Utsman telah memberikan kesempatan kepada pendukung Ali untuk berusaha mengembalikan kepemimpinan atau jabatan khalifah kepada ahlul bait. Oleh karena itu api pemberontakan mulai dinyalakan oleh Abu Dzar al Ghifari dengan menghasut Ibnu Saba yang hidupnya suka berpindah-pindah dari wilayah pemerintahan muslim yang satu ke wilayah pemerintahan muslim yang lainnya.

Ibnu Saba telah memberikan tambahan bahwa Nabi Muhammad adalah orang yang berhak untuk kembali daripada Isa As. Dalam hal ini timbullah dalam Islam mazhab bersemayamnya arwah-arwah, yakni keluarnya ruh dari jasad yang satu dan besemayam kedalam jasad yang lain (mazhab Ar Raj'ah). Tidak hanya itu bahwa Ibnu Saba pun telah menyebarkan mazhab Al Wishayah yang terambil dari ajaran 
Yahudi yang di anut sebelumnya. Dalam mazhab ini Ibnu Saba menganggap bahwa Ali adalah orang yang menerima wasiat dari Nabi Muhammad sebagai penutup daripada orang-orang yang diwasiatkan sesudah Nabi Muhammad penutup para Nabi. Mereka (Abu Bakar, Umar, dan Utsman bin Affan) adalah perampas hak Ali dalam keimanan dan kekhalifahan. Ibnu Saba juga menggunakan teori Al-Hak Al- Ilahi yakni hak ketuhanan. Arti dari pernyataan ini adalah bahwa Ali adalah sebagai khalifah sesudah Nabi dan bahwa hak tersebut bersumber dari Allah swt.

Syi'ah berkeyakinan bahwa suksesi khalifah merupakan proses wasiat. Hal ini mengandung arti bahwa Rasulullah Saw. telah mewasiatkan kepada Ali. Sudah seharusnya Ali mewasiatkannya kepada Hasan dan Hasan akan mewasiatkan kepada Husein dan begitu seterusnya sebagaimana lazimnya pewarisan tahta. Di sisi lain bahwa mereka yang menganggap bahwa Syi'ah adalah pemahaman politik semata, juga memiliki dalil yang kuat. Di antara dalih tersebut bahwa tampuk kepemimpinan umat bukanlah sesuatu yang dapat dibenarkan dan diakui dalam Islam.

\section{Syi'ah Pada Masa Muawiyah}

Sejak Al Hasan menyerahkan kursi kekahlifahan kepada Muawiyah, semangat untuk menjadi kelompok kaum Syi'ah menjadi padam dalam diri penduduka Kuffah, lalu mereka pun bernaung dibawah panji kepemimpinan Muawiyyah yang sudah menjadi penguasa mutlak setelah Al Hasan turun dari tahta kekhalifahan dan pergi meninggalkan Kuffah menuju Madinah. Hanya saja cacian terhadap Ali bin Abi Thalib dan keluarganya diatas mimbar politik yang ditempuh oleh Muawiyah telah menimbulkan kebencian kaum Syi'ah kepadanya. Hal ini bermula ketika Muawiyah mengangkat AlMughirah bin Syu'ban sebagai Gubernur Kuffah ia telah 
memerintahkan untuk mengutuk Ali. Suatu ketika ia berdiri untuk berpidato dan pidatonya itu ia telah mengutuk Ali dan menyanjung Utsman sehingga bangkitlah Hajar bin Addi lalu berkata kepadanya : "Sesungguhnya orang yang engkau caci dan engkau hina, sungguh dengan kemuliaan ia lebih berhak. Dan sesungguhnya orang yang engkau sucikan dan engkau agungkan, sungguh dengan cacian ia lebih berhak." 5

Konflik ini tetap berlanjut sampai Ziyad bin Abihi sebagai pengganti Al-Mughirah bin Syu'ban sebagai gubernur Kuffah. Namun langkah yang diambil oleh Ziyah bi Abihi sama dengan pendahulunya yaitu senantiasan mencaci Ali bin Abi Thalib dan Mengagungkan Utsman bin Affan. Langkah ini membuat Hajar dan pengikutnya semakin naik pitam sehingga mereka melakukan pertemuan untuk mencaci Muawiyah. Namun pertemuan itu tercium oleh Ziyad, maka ia pun berangkat dari Basrah menuju Kuffah dan menyuruh polisi untuk menangkapnya dan membawa Hajar kepadanya. Tidak lama kemudian Ziyad mengirim Hajar bersama dengan para sahabatnya kepada Muawiyah. Tercatat bahwa Muawiyah telah membunuh delapan orang diantara mereka dan mengampuni enam orang lainnya yang menyatakan berlepas diri dari Ali bin Abi Thalib (51 H). ${ }^{6}$ Dengan demikian melemahlah kekuatan kaum Syi'ah dan sikap ingin menjadi kelompok Syi'ah menjadi hal yang teoritis saja.

\section{Pemikiran Politik dan Imamah}

Syi'ah lahir sebagai reaksi atas mayoritas kelompok Sunni yang sejak wafatnya Nabi Muhammad Saw. telah mendominasi dalam percaturan politik Islam serta ketidak setujuan atas kekhalifahan Abu Bakar dan berpendirian bahwa yang berhak

${ }^{5}$ Ath Thabari, jilid 6 hlm. 150

${ }_{6}^{6}$ Hasan Ibrahim Hasan, Sejarah Kebudayaan Islam jilid 2 (Jakarta: Kalam Mulia, 2011), hlm. 223

Sangaji Jurnal Pemikiran Syariah dan Hukum 
menjadi khalifah adalah Ali. Pendapat yang paling populer adalah bahwa Syi'ah lahir setelah gagalnya perundingan antara pihak pasukan Ali dan Mu'awiyah bin Abu Sufyan pada perang Siffin, yang lazim disebut sebagai peristiwa at-Tahkim atau arbitase.

Hal ini senada dengan apa yang menjadi pernyataan Ibnu Saba' bahwa : "Sesungguhnya Utsman telah mengambil jabatan Khalifah tanpa hak, pada hal Ali bin Abi Thalib adalah orang yang diwasiatkan oleh Rasulullah Saw. untuk jabatan tersebut. Dengan demikian, bangkitlah dan bergeraklah kalian untuk urusan kekhalifahan ini. Mulailah kalian dengan menikam para pemimpin kalian dan tegakkanlah al amr bilmakruf wanahyu anilmungkar. Jadilah kalian sebagai pembela rakyat dan serulah mereka pada urusan ini."7

Pada perkembangan selanjutnya, aliran Syi'ah ini terpecah menjadi puluhan cabang atau sekte, hal ini disebabkan karena cara pandang yang berbeda dikalangan mereka mengenai sifat imam $M a^{\prime}$ shum atau tidak dan perbedaan didalam menentukan pengganti imam. Kaum Syi'ah menetapkan bahwa seorang imam:

- Harus $M a^{\prime}$ shum (terpelihara) salah, lupa, dan maksiat.

- Seorang imam boleh membuat hal luar biasa dari adat kebiasaan.

- Seorang iam harus memiliki ilmu yang meliputi setiap sesuatu yang berhubugan dengan syari'at.

- Imam adalah pembela agama dan pemelihara kemurnian dan kelestarian agar terhindar dari penyelewengan.

\section{Hukum Menegakkan Imamah}

Sebagaimana telah dijelaskan di awal bahwa seluruh Aliran Syi'ah sepakat bahwa imamah bukanlah kepentingan umum, yang persoalannya diserahken kepada masyarakat

${ }^{7}$ Ath Thabari, (peneerbit Dzu Ghawiyah), Jilid 1, hlm. 2942 
serta pengangkatannya. Imamah merupakan salah satu akidah yang mendasar serta menjadi salah satu hal yang sangat prinsip dalam Islam. Dalam pandangan Syi'ah seorang Imam memiliki sifat yang ma'sum yakni terbebas dari dosa-dosa besar dan dosa kecil.

Syi'ah meyakini bahwa Ali bin Abi Thalib telah diangkat oleh Rasulullah Saw. menjadi imam berdasarkan teks-teks yang mereka kutip dan mereka takwilkan sesuai dengan aliran mereka. Menurut mereka, teks-teks tersebut terbagi dalam dua bagian; Jali (tersurat) dan khafi (tersirat). Teks yang tersurat adalah sabda Rasulullah saw "barangsiapa yang menajdikan aku sebagai tuannya maka ali adalah tuannya"8

Berdasarkah teks tersebut mereka mengatakan bahwa kepemimpinan ini tidak dapat dilimpahkan kepada siapapun kecuali kepada Ali bin Abi Thalib. Karena itu, Umar bin khattab berkata kepadanya, "Kamu telah menjadi pemimpin semua orang mukmin, baik laki-laki maupun perempuan. ${ }^{9}$

Imamah tidak mempunyai pengertian, kecuali menetapkan keputusan berdasarkan hukum Allah. Inilah yang dimaksud dengan pemerintahan yang wajib ditaati. Oleh karena itu imam Ali bin Abi Thalib mendapat mandat untuk menetapkan hukum dalam masalah imam ketika terjadi pertemuan di Tsaqifah Bani Sa'idah, dan tidak yang lain.

Adapula yang mengatakan bahwa teks-teks tersebut menunjukan pengangkatan Ali bin Abi Thalib sebagai pemimpin berdasarkan deskripsi karakter dan bukan

${ }^{8}$ HR. At-Tirmidzi dalam kitab Al-Manaqib, no 19, Ibnu Majah, dalam AlMuqaddimah, no 11, Ahmad, 1/84, 118,119, 152, dan 321, 4/281, 368, dan 372, dan 5/347, 366, dan 419.

${ }_{9}^{9}$ Ibnu Khaldun, Muqaddima ... hlm. 350

Sangaji Jurnal Pemikiran Syariah dan Hukum 
penunjukan secara langsung. Mazhab ini memiliki pemikiran terbatas. Mereka tidak dapat menempatkan karakter-karakter tersebut secara proporsional, baik dari mazhab zaidiyah atau yang lainnya. Golongan ini tidak mencela Abu Bakar dan Umar dan tidak pula peduli dengan kepemimpinan mereka berdua, meskipun mereka berpendapat bahwa Ali bin Abi Thalib lebih utama daripada keduanya. Mereka memperbolehkan kepemimpinan orang yang tidak diutamakan (al-mafdhul) meskipun ada yang diutamakan (al-fadhil). ${ }^{10}$

Adapula mazhab Syi'ah yang berpendapat bahwa imamah setelah Ali bin Abi Thalib dan kedua putranya, meski terdapat perbedaan antara mereka dan dilimpahkan kepada saudara mereka berdua yaitu Muhammad bin alHanafiyah, lalu kepada putranya. ${ }^{11}$

Diantara golongan-golongan tersebut terdapat kalangan ekstrim yang melebihi batas-batas rasionalitas dan keimanan. Mereka mempertuhankan para imam tersebut, baik dalam posisinya sebagai manusia yang mendapat sifatsifat ketuhanan maupun tuhan yang menitis dalam dirinya sebagai manusia. Inilah pendapat yang menganut paham Al-Hulul atau Reingkarnasi (penyatuan zat Allah dengan dzat manusia), yang sama dengan kepercayaan orang-orang kristen tentang ketuhanan Isa As. ${ }^{12}$

Orang-orang yang berpendapat demikian mendapat kemurkaan dari Imam Ali bin Abi Thalib. Muhammad bin al-Hanafiyyah mengungkapkan kemarahanya kepada alMukhtar bin Abi Ubaid ketika mendengar paham semacam ini, seraya mengutuknya dengan keras dan dia tidak bertanggung jawab atas pernyataan tersebut. Sikap yang

\footnotetext{
${ }^{10}$ Ibid, hlm. 351

${ }^{11}$ Ibid, hlm. 352

12 Ibid, hlm 353
} 
sama juga diperlihatkan Ja'far Ash-Shadiq terhadap orang yang menyampaikan informasi semacam itu kepadanya.

\section{Faksi-Faksi Utama Syi'ah}

Diantara sekian banyak sekte, terdapat 3 sekte besar dan berpengaruh dalam mazhab Syi'ah hingga sekarang yaitu: Zaidiyyah, Ismailiyyah (Sab'iyyah), dan Imamiyah (Isna' Asy'ariyah).

\section{a) Faksi Syi'ah Zaidiyah}

Syi'ah Zaidiyah tidak menganut paham dan teori imam tersembunyi. Bagi mereka seorang imam harus memimpin umat dan berasal dari keturunan Ali dan Fatimah, Syi'ah Zaidiyah tidak meyakini bahwa Nabi telah menetapkan orang dan nama tertentu untuk menjadi imam. Nabi hanya menetapkan sifat-sifat yang mesti dimiliki seorang imam yang akan menggantikan beliau. Terjadinya pengkultusan terhadap diri Ali oleh kaum Syi'ah sebagaimana dijelaskan oleh Suyuti tidak bisa lepas dari pendapat Khawrij yang mengkafirkan Ali sejak peristiwa tahkim (Arbitrase). Tentunya untuk mengimbangi pernyatan dari kaum yang mereka anggap berseberangan dengan mereka ini maka kelompok Syi'ah membuat doktrin untuk menyeimbangi hal tersebut, yaitu mengangkat dan mengkultuskan pada tingkat ma'shum, dan mendoktrin bahwa ia telah ditetapkan melalui wasiat Nabi sebagai imam untuk pengganti Nabi.

Mazhab Syi'ah ini tidak mencela Abu Bakar dan Umar dan tidak pula peduli dengan kepemimpinan mereka berdua, meskipun mereka berpendapat bahwa Ali bin Abi Thalib lebih utama daripada keduanya. Mereka memperbolehkan kepemimpinan orang yang tidak diutamakan (al-mafdhul) meskipun ada yang

Sangaji Jurnal Pemikiran Syariah dan Hukum 
diutamakan (al-fadhil). ${ }^{13}$ Meskipun mereka berbeda pendapat tentang pewaris sah untuk menduduki jabatan imam atau khalifah setelah Ali bin Abi Thalib.

Dalam pengangkatan imamah, Syi'ah zaidiyah selalu melimpahkan kepada ulama mazhabnya dengan melalui pemilihan majelis perwakilan rakyat, dan bukan melalui penetapan. Karena itulah mereka mengakui kepemimpinan Ali bin Abi Thalib, lalu kepada putranya Hasan, lalu kepada saudaraaanya Al- Husain, lalu kepada putranya Zaid bin Ali. Kelompok Syi'ah Zaidiyah ini terbagi menjadi tiga keompok kecil yaitu (1) alJarudiyyah, (2) As-Sulaimiyyah dan (3) Batriyyah dan ash shalihiyyah. Kedua kelompok yang terakhir ini berpandangan sangat mirip.

Dalam mazhab Syi'ah Zaidiyah juga berpendapat bahwa kepemimpinan tersebut dilimpahkan kepada keturunan Fathimah, tetapi melalui seleksi para pemuka agama. Disyaratkan pula hendaknya imam tersebut adalah orang yang mumpuni keilmuannya, zuhud, dermawan, pemberani, dan berkampanye mempopulerkan imamahnya. Ketika muhammad al Baqir memperdebatkan masalah imamah dengan zaid bin Ali bin al Husain tentang kepemimpinan Abu Bakar dan Umar bin Khattab, dimana Zaid bin Ali bin Al Husain mengakui kepemimpinan keduanya dan tidak mencelanya, maka mereka (kelompok Al-Baqir) menolaknya dengan enggan mengakui bahwa Zaid bin Ali bi al-Husain sebagai pemipmin. Karena itulah mereka dinamakan Ar-Rafidhah. ${ }^{14}$

${ }^{13}$ Ibnu Khaldun, Muqaddiman... hlm. 351

${ }^{14}$ Ibid, hlm 352 
Adapun nama-nama imam dalam tubuh golongan Syi'ah Zaidiyah : Ali bin Abi Thalib, Hasan ibn Ali, Husein Ibn Ali, Ali Zaenal Abidin, Zaid ibn Ali.

\section{b) Golongan Syi'ah Ismailiyyah (Sab'iyyah)}

Syi'ah Ismailiyyah berbeda dengan Syi'ah itsn Asyyriyyah dan juga berbeda dengan Musawwiyah, ismailiyah mengakui imamah Ismail Ibn Ja'far ialah putra Ja'far Ash Shadiq yang menurut mereka ditetapkan sebagai imam menurut takdir Allah, menurut mereka Ja'far Ash Shadiq tidak pernah kawin dengan seorang wanita dan tidak pernah mengambil jariah selama ibu Ismail masih hidup. Syi'ah Ismailiyah menisbahkan kepada imam Ismail. Mereka juga dikenal dengan albathiniyah yang dinisbahkan kepada keyakinan mereka tentang imamah yang tidak tampak atau yang menghilang. Mereka juga dikenal sebagai Al-Nulhidah (kaum yang kufur) oleh masyarakat karena dinisbahkan pada sebagian keyakinan mereka yang dianggap kufur.

Mereka memiliki pernyataan-pernyataan lama dan baru yang dipropagandakan Al-Hasan Bin Muhammad Ash-Shabah pada akhir abad kelima, dan berhasil mengguasai benteng di syam dan irak. Mereka berdakwah disana hingga mengalami keruntuhan oleh para penguasa turki di mesir dan penguasa tatar di Irak.

Mazhab ini merupakan pecahan dari mazhab Imamiyah yang disebabkan oleh adanya perbedaan pendapat yang bermula pada Ja'far ash-shadiq yang melimpahkan imamah kepada putranya Ismail, yang lebih dikenal dengan panggilan al-Imam. Menurut mereka, meskipun Ismail meninggal dunia sebelum ayahnya adalah tetapnya imamah pada keturunannya seperti halnya kisah Nabi Harun dan Nabi Musa.

Sangaji Jurnal Pemikiran Syariah dan Hukum 
Syi'ah Sab'iyah atau Ismailiyyah disebut-sebut muncul sesudah tahun $200 \mathrm{H}$. Muncul mula pertama di Irak untuk kemudian mengalihkan geraknnya di persia, turkistan, khurasan, dan India. Selama rentang abad ke 2 $\mathrm{H}$ hingga $4 \mathrm{H}$, sekte ini secara ekstensif menyebarkan ajarannya sehingga pernah tercatat dalam sejarah sebagai aliran terkuat di dunia Islam mulai Afrika hingga India. Sedangkan di ranah politik keturunan Isma'il dalam perjalanan sejarahnya berhasil menguasai mesir dan mendirikan dinasti Fatimiyyah. Dalam perkembangannya Aliran ini telah pula melahirkan bermacam-macam sub-sekte baru seperti Ta'limiyah, mubarakiyah, Qaramitah yang dikenal paling agresif, dan Druzziyah, al-Hashashin, dan lain-lain.

Nama-nama imam golongan Syi'ah Isma'iliyah atau Sab'iyah: Ali bin Abi Thalib, Hasan ibn Ali, Husein ibn Ali, Ali Zaenal Abidin, Muhammad al Baqir, Ja'far al Shadiq, Isma'il ibn Ali.

\section{c) Golongan Syi'ah Imamiyah (Isna' Asy'ariyah)}

Mazhab Syi'ah Imamiyah adalah permintaan Rasulullah Saw. kepada Ali bin Abi Thalib untuk membacakan surat Bara'ah ketika diturunkan pada musim haji. Pada awalnya, Rasulullah Saw. memerintahkan kepada Abu Bakar, kemudian beliau mendapat teguran melalui wahyu agar surat tersebut disampaikan salah seorang dari keturunan beliau atau dari bangsanya. Berdasarkan wahyu ini, maka Rasulullah memutuskan untuk menggutus Ali bin Abi Thalib untuk membaca surat tersebut.

Mereka beranggapan bahwa perintah ini menunjukan bahwa Rasulullah Saw. lebih mengutamakan Ali bin Abi Thalib. Disamping itu juga bahwa belum pernah dikenal dalam sejarah bahwa 
Rasulullah mengutamakan sahabat lain daripada Ali bin Abi Thalib. Adapun mengenai Abu Bakar dan Umar, maka beliau pernah mengutamakan Usamah bin Zaid dan Kemudian Amr bin Al-Ash di atas keduanya dalam dua peristiwa perang. ${ }^{15}$

Sebagian mazhab Syi'ah berpendapat bahwa teksteks tersebut menunjukan pengangkatan Ali bin Abi Thalib sebagai pemimpin sekaligus penunjukan secara langsung. Darinya akan diwariskan dan diwariskan kepada generasi sesudahnya dari ahlul bait lewat penunjukan. Mazhab yang berpendapat demikian adalah mazhab Syi'ah Imamiyah. Mereka mengenyampingkan kedudukan Abu Bakar dan Umar bin Khattab karena keduanya tidak mendukung dan membaiat Ali sebagai pemimpin berdasarkan teks-teks ini.

Lebih lanjut dalam pandangan Syi'ah Imamiyah bahwa imamah tersebut diserahkan kepada keturunan Fathimah berdasarkan teks satu demi satu, yang dinisbatkan kepada pernyataan populer mereka yang mensyaratkan pengetahuan imam dan pengangkatannya mengenai imam. Ini merupakan pokok keyakinan menurut mereka. ${ }^{16}$

Mazhab Syi'ah imamiyah atau itsna asyariyyah berkeyakinan bahwa imam dua belas yang dinisbahkan kepada Muhammad bin Al Hasan al Askari yang diberi gelar Al Mahdi, keyakinan mereka ini didasarkan kepada hadits yang terdapat dalam sunan at-tirmidzi tentang imam mahdi.

Nama-nama imam golongan Syi'ah Imamiyyah atau Isna 'Asyariyah : Ali bin Abi Thalib, Hasan ibn Ali,

15 Ibid, hlm. 350

${ }^{16}$ Ibih, hlm. 351

Sangaji Jurnal Pemikiran Syariah dan Hukum 
Husein ibn Ali, Ali Zaenal Abidin, Muhammad al Baqir, Ja'far al Shadiq, Musa al Kadzim, Ali al Ridho, Muhammad al Taqi', Ali al Hadi, Hasan al Askari, Muhammad al Mahdi.

\section{E. Kesimpulan}

Dari penjelasan di atas dapat ditarik kesimpulan bahwa dalam pergolakan politik mazhab Syi'ah dalam pentas sejarah Islam melahirkan paham dan sekte-sekte yang beragam dan saling berseberangan ada yang ekstrem dan ada yang moderat. Para pemimpin dalam sekte Syi'ah salaing mengklaim dan berebut pengaruh untuk mendapatkan pengikut dari dulu hingga sekarang.

Dalam pentas sejarah Islam keberadaan Syi'ah dari awal khalifah Dinasti Muawiyyah tidak begitu mendapat dukungan dari khalifah karena keberadaan mereka selalu ditekan sehingga mereka cenderung melakukan gerakan tersembunyi atau menyembunyikan setiap identitas mereka dalam pentas perpolitikan masa itu, baik pada masa Dinasti Muawiyah dan Abbasiyah. Akan tetapi harus diakui dalam peta sejarah Islam Mazhab Syi'ah telah mampu membangun sebuah peradaban dan memberikan kontribusi dalam peradaban Islam ketika mazhab Syi'ah Ismailiyah membangun dinasti Fatimiyyah di Mesir.

Konsep imamah dalam Mazhab Syi'ah merupakan konsep yang mempercayai Ali bin Abi Thalib yang berhak menggantikan posisi Nabi Muhammad sebagai pemimpin agama dan pemimpin Negara dari pada sahabat seperti Abu Bakar, Umar bin Khattab dan Utsman. Sebagian sekte-sekte tersebut tidak mengakui akan kepemimpinan Abu Bakar. Umar, dan Utsman dan menganggap mereka telah merampas hak Ali bin Abi Thalib sebagai penerima wasiat dari Nabi. Namun disisi lain sekte-sekte syi'ah ada juga yang mengakui 
dan menerima kepemimpinan Abu Bakar, Umar, dan Utsman, sebagaimana halnya Syi'ah Zaidiyah namun tidak semua pecahan dari sekte Zaidiyah ini memiliki satu pendapat tentang hal demikian.

Sangaji Jurnal Pemikiran Syariah dan Hukum 


\section{Daftar Pustaka}

Iqbal, Muhammad, Fiqih Siyasah: Kontekstualisasi Doktrin Politik Islam, Jakarta: Gaya Media Persada, 2001.

Nasution, Harun, Teologi Islam: Aliran - Aliran Sejarah Analisa Perbandingan, Jakarta: UI Press, 1986.

Pulungan, Suyuti, Fiqih Siyasah: Ajaran, Sejarah dan Pemikiran, Jakarta: PT.Raja Grafindo Persada, 2002.

Sjadzali, Munawir, Islam dan Tata Negara: Ajaran, Sejarah dan Pemikiran, Jakarta: UI Press, 1990.

Zahrah, Imam Muhammad, Tarikh al - Madzahib al - Islamiyyah, terjemahan Abd. Rahman Dahlan dan Ahmad Qarib, Aliran Politik dan Aqidah Dalam Islam, Jakarta: Logos, 1996,

Ibnu Khaldun, Muqaddimah, terj. Masturi Ilham, Malik Supar, Abidun Zuhri, Jakarta. Pustaka Al-Kautsar, 2011

Muhammad Affan, dkk, Bara Api di Pulau Garam: Mengurai konflik Syi'ah-Sunni di sampang Madura, yogyakarta: Suka Press, 2014

Nourouzzaman Shiddiqi, Jeram-Jeram Peradaban Muslim, Yogyakarta, Pustaka Pelajar Offset, 1996

Fuad Moh. Fazhruddin, Pemikiran Politik Islam, Jakarta: CV. Pedoman Ilmu Jaya, 1988

Mustafa Muhammad Asy-Syak'ah, Konflik antar Mazhab dalam Islam, Bandung, Pustaka Setia, 2013

W. Montgomery Watt, Politik Islam Dalam Lintasan Sejarah, Jakarta: CV Guna Aksara, 1988

Hasan Ibrahim Hasan, Sejarah dan Kebudayaan Islam, Jilid 2, Jakarta: Kalam Mulia, 2011

Ira M. Lapidus, Sejara Sosial Umat Islam, terj. Jakarta: PT. Grafindo Persada, 1999

Asy-Syahrastani, Al-Milal Wa Al-Nihal, Terj. Jilid 1, Surabaya: PT. Bina Ilmu, 2006 